\title{
The Role of the Parallel Corpus in Linguistics, the Importance and the Possibilities of Interpretation
}

\author{
Karimov Rustam Abdurasulovich, Mengliev Bakhtiyor Rajabovich
}

\begin{abstract}
Convenient interface and search engine in the language corpus serves as an object of research. The development of corpus linguistics has become the basis for the development of language awareness, linguistic competence, philological sciences and technology. The research is mostly based on the analysis of parallel corpus and its possibilities in Uzbekistan.
\end{abstract}

Keywords : Linguistic corpus, language, parallel corpus, grammatical interpretation, corps-based lexicographical analysis, interface, search engine.

\section{INTRODUCTION}

$T_{\text {he years in the usage of linguistic corpus made it much }}$ easier for the linguists to learn the presence of observation, sample / evidence collection, comparison, and conclusions facilitated this study. Convenient interface and search engine in the language corpus serves as an object of research.

The proof of the grammatical interpretation of the speech of the linguists was no longer a novelty for the age of corpus linguistics. Typical cases, examples of ten, hundred, and thousands of examples in the corpus studies help the researcher to conclude; unusual situations also create new theoretical views. In other words, new discoveries in the speech, new combinations and structures allow for new hypotheses in linguistics.

The development of corpus linguistics has become the basis for the development of master's programs on the RuN-Euro Corps project in the higher education institution; Masters conduct research on contrastive linguistics on this basis.

\section{LITERATURE REVIEW}

At the time of comparing Russian, Norwegian and English languages, master's thesis, doctoral dissertations are being used. For example, a study of the qualitative and quantitative approach differences. Russian, Norwegian, and English-speaking circles were summarized based on statistical methods based on parallel corpus samples. Among the master's and PhD researches we can include: "Вид в славянских императивах" (Alvestad, PhD 2013), "Реалии в переводах с русского на норвежский"

Revised Manuscript Received on July 22, 2019.

Karimov Rustam Abdurasulovich, A senior teacher of Bukhara State University,Uzbekistan. Email: rustamkarimov83@mail.ru

Mengliev Bakhtiyor Rajabovich, A professor of Tashkent State Uzbek language and literature University name after Alisher Navoiy. Email: bmengliev@inbox.ru
(Kharina, PhD 2013-15), “Дискурсивные частицы в сопоставлении”, “Интерпретация и перевод местоимений с -то/-нибудь”, “Перевод на норвежский глаголов начинательного способа действия с предлогами по- и за-".

In these investigations, the corpus was a source of research. E.Sosnina explains the use of parallel corps in language teaching: "Examples from the corpses help in language teaching. The student will be given a material that will give a clear picture of the use of intercultural communication from real speaking situations for practical assignment and analysis. The general shortcoming of many textbooks is that the examples in them are typically written and written by the author, and their conclusions are based on the opinion of one or two people. ". The corpus can also be used to analyze material that is available in foreign language education and identify deficiencies. These studies have a general methodological character - a typical textbook, glossary and case studies analyzed by a particular structure / lexicon; then the result from both sources is compared. Many of these studies have led to the following conclusion:

\section{1) The textbook "teaches" how the learner speaks, as it is shown on the language corpus;}

2) some textbooks ignore more important aspects or are rarely used as examples (this is a general lack of textbooks);

3) The educational material ignores the real context, distracts the reader, reduces the intensity of language acquisition.

Thus, the parallel corpus is a modern learning tool that offers a set of materials for linguistic research.

\section{METHODS AND ANALYSIS}

Let's talk about the role of parallel corpus in foreign language teaching.

The first example. As you know, there is a predlog (preposition) category in Russian. Prepositions in Russian are translated into English. Parallel corpus statistical analysis shows a systematic difference in the use of prepositions in different speech situations. An analysis of the examples in the application shows that neither prepositions have different content in translation; 
the use of preposition in English is a challenge for a reader who is in the early stages of learning the language.

The second example. Another phenomenon that is difficult for a reader to learn is the use of verb forms, in particular the use of verbs. In some cases the meaning of the verb in translation varies and is understood from the context.

Here is an easy way to translate these verbs and learn from them in terms of parallel case examples. Seven examples of the use of these verbs in the parallel corpus (Context-Context) help to draw conclusions (see Annex 1). As you can see from the table the meaning of the word "put" in the translation dictionary is not sufficient to translate verbs. In this case, the student makes conclusions based on corpus material, enriches his / her knowledge, and sees the meaning in a realistic contextual context.

Third example. There are many synonyms in the language. In the dictionary and the thesis, the meaning of these words is closely related to each other. Synonymic words differ from one another to a different style when used in different speech situations. Corps-based lexicographical analysis allows you to observe the use of different linguistic units in different situations; it will allow you to come up with the right conclusion as you observe a large number of contexts. Let's look at the words as big, large and great from the corpus. In Thesaurus, these words are regarded as meaningful words that express the size. In the examples from the Russian-English parallel corpus, they are used as follows:

\begin{tabular}{|c|c|}
\hline $\begin{array}{l}\text { Следует сказать, что Дидро не верил } \\
\text { вначале в возможность создания в } \\
\text { Петербурге большой картинной галереи. }\end{array}$ & $\begin{array}{l}\text { It should be noted that Diderot } \\
\text { first did not believe in the } \\
\text { possibility of collecting a big } \\
\text { picture gallery in Petersburg. [28] }\end{array}$ \\
\hline $\begin{array}{l}\text { Но все больше фактов свидетельствуют } \\
\text { - том, что самые большие опасности } \\
\text { заключает в себе экипаж. }\end{array}$ & $\begin{array}{l}\text { But there is increasing evidence } \\
\text { to show that one of the greatest } \\
\text { hazards lies in the crew itself.[30] }\end{array}$ \\
\hline $\begin{array}{l}\text { За годы своего существования он } \\
\text { превратился из дворцовой галереи в музей, } \\
\text { выделяющийся в ряду крупнейших музеев } \\
\text { мнра разносторонностью своего собрания. }\end{array}$ & $\begin{array}{l}\text { From a palace's picture gallery } \\
\text { it went down to our time as one of } \\
\text { the world's largest museums } \\
\text { distinguished for versatility of its } \\
\text { collection.[28] }\end{array}$ \\
\hline
\end{tabular}

The analysis of the examples shows that the word big means greater than the essential meaning of the word, and the word big and great is not limited to this. Words as large and big of elongated quality are more frequently found in stable compounds. Great is used to express more emotions: great weariness, great feeling. The Russian-English parallel corpus clearly shows the use of synonyms. Dictionaries do not contain such information. Another difference between them is that they are part of the word combination of lexemes. It is unacceptable to replace the quality with its synonyms such as big noise, big head. It's not always possible to replace the word with synonym, while maintaining the content.

\begin{tabular}{|l|l|}
$\begin{array}{ll}\text { I like you and it's obvious you're } & \text { Ты мне нравишься, и я рад, что к тебе } \\
\text { a big hit with the pretty girls. } & \text { липнуг хорошенькие девчонки.[29] }\end{array}$ \\
\hline
\end{tabular}

\begin{tabular}{|c|c|}
\hline $\begin{array}{l}\text { With a feeling of great } \\
\text { weariness, Garraty looked down at } \\
\text { Gary Barkovitch. }\end{array}$ & $\begin{array}{l}\text { Это, конечно же, был Баркович. } \\
\text { Гэррети почувствовал, что его усталость } \\
\text { растет.[29] }\end{array}$ \\
\hline $\begin{array}{l}\text { He thought about a great big } \\
\text { chocolate cake with a cherry on the } \\
\text { top. }\end{array}$ & $\begin{array}{cccc}\text { Потом } & \text { подумал } & \text { о } & \text { большом } \\
\text { шоколадном } & \text { торте } & \text { с } & \text { вишенкой } \\
\text { наверху.[29] } & & & \end{array}$ \\
\hline
\end{tabular}

When the students translate the phrase into a nonsense speech, they often use clause (she said that; This leads to a kind of storytelling. The parallel corpus helps the student find the synonym of the verb (ie, not just to say). The latter is often used in a newspaper article. These articles are the result of the speech of art and politicians.

\begin{tabular}{|c|c|}
\hline \begin{tabular}{ll}
\multicolumn{1}{c}{ Теперь } & президент США дает \\
российской газете интервью, в котором \\
открыто говорит о проблемах, \\
вызывающих беспокойство у Запада.
\end{tabular} & $\begin{array}{l}\text { Now the U.S. president has } \\
\text { given an interview to a Russian } \\
\text { newspaper in which he raises } \\
\text { publicly many Western concerns. }\end{array}$ \\
\hline
\end{tabular}

(Annex 3)

Fifth example. The student also gives a methodological error. Selection of contexts in different genres from the parallel corpus will also prevent the methodological errors allowed. The exhibition material is always more clear than the verbal statement; it will be easy to store in memory.

\begin{tabular}{|c|c|}
\hline Dear Prof. Rosher, ?. Regards & Уважаемый професcop Pomep!?.. \\
\hline (Annex 4)
\end{tabular}

The lack or lack of visual material on the actual speech situation is a barrier to correcting a student's speech failure. The parallel corpus is a good educational tool that can be used in foreign language learning. Without such educational resources, relying solely on textbooks and dictionaries is based on theoretical knowledge. The parallel corpus genre refers to contextual contexts; collects an infinite sample of examples and resources. At the same time, the process of gathering materials, analyzing, summarizing and summarizing information on parallel frameworks in foreign language education requires students to work independently. The student's ability to work independently increases.

Independent judgment - easy to remember is a proven process. By comparing parallel cores and translated dictionaries, it should be noted that the only meaning of the word is that the equivalent of translation in the study of words and phrases not mentioned in dictionaries is superior to parallel corpus translation dictionaries. Below we present samples of teaching assignments that can be performed on a case-by-case basis. 1. Follow the translation and translation of predogs (eg about / about). 2. Follow the combination of punctuation marks in compound sentences.

Use the words tell / say, listen / hear in the parallel case to see the place, and make conclusions on a static basis. 4. Analyze the differences between terms such as information retrieval / searcher on parallel case studies. Find examples of use of the word run in context; separate the semiclores. 6 . Find international words from the parallel corpus. Are their meanings and translation meanings appropriate? Conclude by saying this. Use of parallel bodies in translators education. 
Gyorn describes the experience of using parallel corpus translators in teaching:

"This program is primarily intended for teaching translation theory and practice, as well as for independent study of Russian language, so the program basically uses bachelors, masters and postgraduates. It can choose to translate its translation online, compare with the language version of the database, read comments, track other translations, show typical errors, and respond to their work, which can be a reliable source for translating translations. "

The authors of the program extracted 12 fragments from the Russian-Norwegian translation texts from the RuN-Euro Corps. Later on, 8-10 Russian speakers were asked to translate these inscriptions into Russian. As a result, as the first information, the following content is available:

(Jostein Gaarder, «Sofies verden»/«Мир Софии»)

1а. София Амуннсен возвращалась домой из школы.

1b. София Амундсен шла по дороге домой из школы.

1с. София Амундсен возвращалась из школы домой.

1d. София Амундсен возвращалась домой из школы.

1е. Софи Амуннсен шла со школы домой.

1f. София Амундсен шла из школы домой.

$1 \mathrm{~g}$. София Амуннсен шла домой из школы.

1h. София Амундсен шла домой после школы.

1i. София Амундсен шла домой из школы.

The example in "1a" is a professional translation of the RuN-Euro Corps. The amateur translators are required to translate in beautiful and smooth style, with original content. It is possible to conclude exactly and concisely how much linguistic the translation of translation (translation by professional translators of Russian literary translators) is translated for contrastive linguistic researches on the basis of systematic comparison of the existing translation and language content of the body. How close are they to the original text?".

\section{DISCUSSION}

An analysis of the translation material collected in the parallel corpus shows that Russian translators prefer a free translator of novel interpreters. " Parallel corps can also be an effective learning resource in translators education. This approach was begun by Austrian linguist M.Vandrushka and his followers. Even the majority of methodological manuals on translation (eg, VK Kabakchi, T.Kazakova's textbooks) are based on parallel corpus materials. These textbooks have an exercise suite for identifying original and translated language equivalents.

The main task of this assignment is to analyze the lexical and grammatical structure of the parallel context. The student is given original and translation (several variants of translation); the source of the review / analysis will be clear; it is only for the students to analyze / synthesize, to make linguistic summaries, to bring the conclusions to the translation skills. In parallel, the parallel corpus provides the advantage of other learning resources as the source of particular resources. In fact, it is desirable for the translation to be carried out with reference to the next editing.

The interpreter (in particular the translator who does not yet have a great experience) needs resources that can serve as
1. Sofie Amundsen var på vei hjem fra skolen.

a translation tool for some or all of the standard constructions. It is reported that during the translation process, 50 or even $80 \%$ of the interpreter goes to work with the dictionary. Electronic parallel cores and computer technology have the potential to significantly reduce this time. They are valuable in demonstrating professional translation samples in the study of translation methods and ways.

The parallel conditional program allows the translator to find the equivalent of a lexical unit of interest, translate, translate, translate, translate, translate, transliteration, the use of idioms, terms, grammar, stylistic trajectories, they can use them in translation. Similarly, parallel corps can also serve as a learning resource for the teacher in translation education. Therefore, the parallel corpus can serve as the educational resource for the teacher and the student.

In the following examples, EP Sosnina gives some examples of the use of parallel frames in translation theory and practice. In his view, PCs in the form of databases are crucial for the process of working with conventionally-bound (conventional) texts. The genre-style characteristic of these texts and the stylistic process do not allow for the avoidance of socio-cultural norms. Such documents include, mainly, business documentation, text of the weather, text of the contract. Texts of different styles are not only aesthetically unique, but also with the help of grammatical, syntactic patterns.

They should appear in the form of an invariant text. The PK sample texts can help with their typological modeling characteristics as an instructive guide for the student translator. There is no doubt that this task can not be achieved by ordinary dictionaries (see Annex 3). When translating a term in a parallel case, assignment is also a good source of search for equivalence. Rapid development in scientific, technological, and political spheres creates problems for translators, leaving behind the creation of terminology dictionaries in the field; as a result, there are conflicting interpretations.

PCs can automatically find the word combination and combination. In such cases, the parallel corpus of scientific, technical, political, economic and legal texts is relevant (see Annex 4).

Using a PC in comparative study of the translation of literary works will be beneficial. For example, the Russian-German PPA has 20 different translations of the novel "Telba": a material that is readily available for learning the theory of translation. Naturally, 20 authors have 20 different styles.

Thus, the accumulation of a translation of a work by different translators in PCs is not only a source of observation of lexical equivalent, syntactic and grammatical structures between two languages, but also as the object of research to serve as the basis for drawing conclusions about a particular translation strategy, by comparing different translations. It can be said that the PK is an example for the visual translator for the student translator or for subsequent translations. By comparing PCs with two-language dictionaries, the following differences are distinguished:

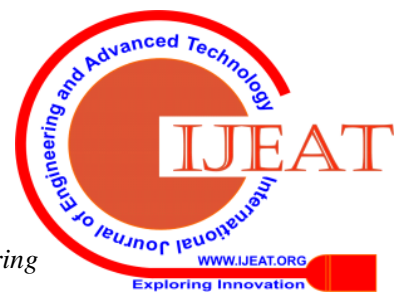


1) a set of two-lingual dictionaries of lexical units and terms; The PC is a collection of computational and translator experience. 2) When the translator finds the equivalent of the translation dictionary, he / she will have to conclude alone that the words or words can be used in the translation text; The PK also serves as a model for many experienced translators for problem situations. 3) PK provides information that is not available in bilingual dictionaries.

They do not offer an equivalent equivalent in a single word, but also help with the translation of the lexical unit, which does not have an equivalent; the translator will demonstrate how he has acted in translating that unity. Parallel corpses can be used in translation training in the following tasks: 1 . Find and describe methods of horse horses translation. 2. How are the terms translated? 3. What is the stylistic structure of business documents? 4. How to translate units that do not have an equivalent?

Identify and analyze textual texts in translation and in the art. What is the maximum number of characters in your language? Describe lexical-grammatical similarities and differences in the use of Russian and English predictions (this assignment can be given in different grammatical forms)

\section{RESULTS AND CONCLUSION}

In conclusion, it should be noted that the corpus-based approach to modern translation education creates new opportunities. In contrast to the National Corps, this body provides a basis for the study of translation features in a specific field based on massive material.

Creating parallel frameworks for scientific, technical, socio-political, economical and other fields allows for a special study of language skills in this area. Today in the world of computer linguistics there are a number of concomitant programs, corpus managers, and a small (parallel and comparative) corpus with special goals. For the Uzbek language such contradictions and corpus managers' development are the most important tasks facing the computer linguistic expert today.

\section{REFERENCES}

1. Тао Ю., Захаров В.П. Разработка и использование параллельного корпуса русского и китайского языков // Автоматизация обработки текста. информ. процессы и системы. - Сер. 2, 2015. № 4.

2. Hu X. Y. Yuliaoku fanyi yanjiu yu fanyi pubianxing // Shanghai keji fanyi. - 2004. - № 4. - P. 47-49.

3. Тао Ю., Захаров В.П. Разработка и использование параллельного корпуса русского и китайского языков // Автоматизация обработки текста. информ. процессы и системы. - Сер. 2, 2015. № 4.

4. Baker M. Corpus linguistics and translation studies: Implications and applications // Text and Technology: In Honour of John Sinclair / eds. F. Baker, Tognini-Bonelli. - Amsterdam/Philadelphia: John Benjamins, 1993. - P. 233-250.

5. Baker M. A corpus-based view of similarity and difference in translation // International Journal of Corpus Linguistics. - 2004. - № 2. - P. 167-193.

6. Barlow M. ParaConc: Concordance Software for Multilingual Parallel Corpora // Proceedings of the Third International Conference on Language Resources and Evaluation. LREC Workshop № 8 : Workshop on Language Resources in Translation Work and Research. - 2002. - P. 20-24

7. http://ruscorpora.ru/corpora-intro.html 